ISSN:2656-4270 (Online) 1410-4466 (Print) Accredited by Ministry of Research, Technology, and Higher Education with the ranking of Sinta (S4) SK NO.28/E/KPT/2019, 26th September 2019
Buletin Penelitian Sosial Ekonomi Pertanian Fakultas Pertanian Universitas Haluoleo

2020:22(1):20-26

http://ojs.uho.ac.id/index.php/sosek

doi: http://dx.doi.org/10.37149/sosek.v22i1.11101

\title{
FARMERS' MOTIVATION ON SEAWEED CULTIVATION IN KAWITE-WITE VILLAGE KABAWO SUB-DISTRICT MUNA DISTRICT
}

\author{
Salahuddin ${ }^{1^{*}}$, Tjandra Buana ${ }^{1)}$, Parto $^{1)}$ \\ ${ }^{1}$ Department of Agriculture Extension Agricultural Faculty of Agriculture Halu Oleo University, \\ Kendari Indonesia 93232 \\ *Corresponding author : salahuddin.saleh16@gmail.com
}

To cite this article:

Salahuddin, S., Buana, T., \& Parto, P. (2020). Farmers' Motivation on Seaweed Cultivation in Kawite-Wite Village Kabawo Sub-District Muna District. Buletin Penelitian Sosial Ekonomi Pertanian Fakultas Pertanian Universitas Haluoleo, 22(1), 20 - 26. doi:http://dx.doi.org/10.37149/bpsosek.v22i1.11101

Received: February 24, 2020; Accepted: August 04, 2020; Published: August 09, 2020

\begin{abstract}
This study aimed to determine farmers' motivation level and farmers' activities in seaweed cultivation in Kawite-Wite Village, Kabawo Sub-District, Muna District. The sample in this study was determined by simple random sampling. This study used interval scale analysis. The results showed that the farmers' motivation level and farmers' activities in seaweed cultivation in Kawite-Wite Village, Kabawo Sub-District of Muna District have been carried out well.
\end{abstract}

Keywords: cultivation; farmers; motivated; seaweed

\section{INTRODUCTION}

Indonesia territory consists of about $70 \%$ of the ocean, which is rich of various types of biological resources. One of them is seaweed which has significant value for Indonesian people. Algae is low level plant which cannot be distinguished between its roots, stems, and leaves. All parts of the plant are called thallus. In general, these plants have similar morphology, although they are actually different (Hernanto, et al, 2015). Algae (seaweed) occupies an important position in Indonesian fishery production, especially in the non-fishery fishery business. Seaweed is one of the main staples in the fisheries sector due to the increasing demand for both domestic and export needs (Awaluddin, et al., 2016). The potential of Indonesian seaweed is very promising and can be a commodity that can plays a role in the movement of national economic progress (Hikmah, 2015).

Indonesia has large seaweed resources in which if it is processed properly, it will be able to produce functional food products for wider community. To be categorized as a functional food product, processed seaweed food products must contain high levels of nutritional, fiber, and bioactive components that are almost the same as raw materials (Erniati, et al., 2016). Algae is widely used because it contains gelatin, fragmentation, porridge, furcellaran, and pigment (consisting of phycoerythrin and phycocyanin), which are food reserves that contain lots of carbohydrates (Kesuma, et al., 2015).

Seaweed can be relied upon as a fishery product to improve the living standards of coastal communities because the technology used is simple and inexpensive, making it suitable for coastal communities with low economic and educational conditions (Fikri, et al., 2015). Currently, the market demand for seaweed needs continues to increase. To meet the market needs, sustainable seaweed production is needed (Awaluddin, et al., 2016).

Seaweed cultivation plays an important role in efforts to increase seaweed production, to meet food and nutritional needs, meet domestic and foreign needs, expand employment opportunities, increase fishermen's income and welfare and conserve water resources. Seaweed cultivation can be used as an alternative source of income. Therefore, it is necessary to increase the quality and quantity of seaweed cultivation so that maximum production can be achieved.

Seaweed cultivation has now developed rapidly. This is due to increased market demand both at domestic and abroad, especially due to the development of an industry based on seaweed raw materials (Priono, 2016). Seaweed cultivation is not only done in coastal waters (sea) but has 
also begun to be developed in brackish waters (ponds). Aquaculture in coastal waters is very suitable to be applied in areas that have little (narrow) land and are densely populated, so it is expected that the clearing of seaweed farming in the waters can be an alternative to help solve the employment and income problems of seaweed farmers (Priono, 2016). Seaweed has high value and benefits so that it can improve the standard of living of the people living in the area. Seaweed cultivation activities must be supported by factors that play a role in the development and management of seaweed culture in a sustainable manner, such as the environment, technology, society, and economy (Sujarwo \& Fitriyanny, 2016).

Seaweed cultivation has spread in various waters in the province of Southeast Sulawesi. Apart from being an export commodity, seaweed cultivation does not require high technology, low cost, and production facilities, provides higher income, does not require large areas of land, short production cycles, and environmentally friendly. These things are some important reasons so that seaweed cultivation is one of the main sectors in the Southeast Sulawesi. The province is has been even known as a seaweed province. Seaweed cultivation in Southeast Sulawesi is one of the fishery resources that has a comparative advantage for the economy of coastal communities.

Seaweed development in Muna District, Southeast Sulawesi Province is supported by its designation as a Minneapolitan area based on the Decree of the Minister of Maritime Affairs and Fisheries No. 32 of 2010. The potential development of seaweed cultivation in Muna District is 33,625 ha, of which its productivity reaches 11.8 tons/ha/year. The development of seaweed cultivation in Muna District still has enormous potential. Among the 33 sub-districts in Muna Districts, 24 subdistricts have coastal areas and have significant potential for the development of seaweed cultivation. One of the villages with seaweed development potential is Kawite-wite Village. The community in Kawite-wite Village, Kabawo Sub-District, Muna District, has been cultivating seaweed since 2002. Initially, only three farmers planted seaweed. From 2003 until now, seaweed cultivation has been developing rapidly, and the community of Kawite-wite village began to depend on seaweed.

Efforts to increase the commercial production of farming require adequate motivation or encouragement to farmers and their families. Motivation is stimulation arising from a person based on the need for an activity carried out to achieve certain goals (Marti, et al., 2014). The success of an agricultural business is certainly influenced by the motivation of farmers, both internal and external motivation (Datika, et al., 2018). Motivation is basically a mental condition that encourages actions or activities and provides strength (energy) that leads to the achievement of needs (Alam, et al., 2014).

The development of seaweed in Kawite-Wite Village is supported by the condition of the region, which is potential, and also supported by its dominant community living along the coast. Most of the people work as seaweed farmers. Seaweed farmers in the region need support for the development of seaweed in the region. There are a number of supporting factors needed for the successful development of seaweed plants.

Seaweed cultivation in Kawite-Wite Village basically has no intervention from extension agents. Even without guidance and direction from the extension staff, farmers who cultivate seaweed in Kawite-Wite Village are still enthusiastic with high motivation. Even though there has been no counseling, the production results have been optimally satisfying for the farmers. The existence of motivational encouragement from the farmers themselves without encouragement from outside parties such as extension workers makes them even more active in trying to develop seaweed to achieve optimal results so that later the production results obtained at harvest can be marketed. Based on the description above, the problem in this study was how the farmer motivation level on seaweed cultivation and how the seaweed cultivation activities in Kawite-Wite Village, Kabawo SubDistrict, Muna District.

\section{MATERIALS AND METHODS}

Descriptive research is a form of research that aims to describe existing phenomena, both natural and artificial. Phenomena can be in the terms of forms, activities, characteristics, changes, relationships, similarities, and differences between one phenomenon and another (Linarwati, 2016). This research was conducted in Kawite-wite Village, Kabawo Sub-District, Muna Distrcit. The population in this study consisted of 316 seaweed farmers (KK). Population is all objects that are examined (symbol: N), while sample is part of the object under study (symbol: $n$ ). The sampling method for members of a large population can range from $10-15 \%$ to $20-25 \%$. The sampling was done using simple random sampling (Suharsimi, 2013). The sample in this study consisted of 44 seaweed farmers, or $20 \%$ of the population, who were randomly selected (random sample). Data were collected and then processed. For statistical analysis, the analytical model used must be in accordance with the research design. The calculation of the motivation level of farmers in seaweed 
cultivation was based on the categorization of respondents' answers into three categories, those are high, medium, and low. The determination of categories using the class interval formula was as follows:

\author{
PK $=[$ Range / (Number of Classes) $]$ (Sunyoto, 2012), where:$$
\mathrm{PK}=\text { class length }
$$ \\ Range $=$ Largest data - Smallest data \\ Number of classes $=$ number of classes determined by the researcher
}

\title{
RESULTS AND DISCUSSION
}

\section{Respondent's Identity}

The identity of the respondents used to describe the respondents in this study included age, education, farming experience, and the area of land that the respondent was working on. The number of respondents in the study was 44 people. The description of the respondents in this study can be seen in Table 1.

Table 1. Characteristics of respondents in Kawite-Wite Village

\begin{tabular}{lcc}
\hline \multicolumn{1}{c}{ Identity } & Total (People) & Percentage (\%) \\
\hline Age (Years) & 39 & \\
15 - 55 (Productive) & 5 & 88,84 \\
$>56$ (Full Productive) & & 11,36 \\
\hline Education & 27 & 61,39 \\
SD & 12 & 27,27 \\
Junior High School & 5 & 11,36 \\
High school & & \\
\hline Experience (Years) & 28 & 63,64 \\
$<5$ (Less Experience) & 16 & 36,36 \\
5 - 10 (Experienced) & - & - \\
$>10$ (Very experienced) & & - \\
Land Area (Ha) & - & 79,55 \\
$<1$ (Inadequate) & 35 & 20,45 \\
1 - 2 (Adequate) & 9 & \\
$>2$ (Very Adequate) & &
\end{tabular}

Source: Processed Primary Data

Young farmers were more motivated, innovative, and riskier than older farmers (Herdiansah, et al., 2018). Table 1 shows that in general, the respondents of this study were in the productive age category $(88.84 \%)$. Farmers in productive age tend to be able to carry out long farming activities well.

Age is one of the factors that influence the success of a farm. Age can affect farmers' physical skills, decision making, and performance in managing their farms. The older the farmer, the more experience he gets and has habits that are difficult to change, which have a big influence on the process of adopting innovation (Anggraeni, 2017). Productive age is not only related to the working capacity of farmers, but also to the level of farmers' food consumption. Farmers at this age certainly still have the capacity to work more and need more energy than farmers at unproductive ages to influence production yields and farm acceptance rates (Yasmiati, 2010).

Farmers with higher education will be more resilient, dynamic and motivated and will be able to optimally use natural resources, energy, capital and technology, and be able to overcome all challenges, threats, obstacles, and disturbances to the existence and conservation of natural resources (Mahyuddin \& Windasari, 2017).

Formal farmer education is also one of the things that can support the success of agricultural management (Yasmiati, 2010). The higher the education level of farmers, the more open their understanding is in accepting agricultural technology innovation (Herdiansah, et al., 2018). Table 1 shows that research respondents generally have gone through primary and secondary education (SD $61.30 \%$, SLTP $27.27 \%$, and SLTA $11.36 \%$ ). The level of education is one aspect that determines the motivation of farmers in cultivating seaweed.

Experience in agriculture is very important in agricultural management, both in the decisionmaking process, in determining the products to be marketed, and in the use of production factors. In general, the greater the experience in agriculture, the more efficient the tendency to use production factors (Anggraeni, 2017). Increasing the experience of farmers increases the technical skills of farmers in doing agriculture so that agricultural productivity can be increased by farmers (Herdiansah, et al., 2018). Table 1 also shows that generally, the research respondents are still inexperienced, 
where the respondent farmers generally had only $<5$ years experience $(63.64 \%)$ in cultivating seaweed. Farming experience is a factor that influences success, including the motivation of a farmer in carrying out agricultural activities.

The area of farmers' land is related to the level of farmers' acceptance from agricultural activities. Farmers who have large areas of land will have high incomes from the cultivation farming (Yasmiati, 2010). Bigger land ownership for farmers, generally will make the farmers to have a better economic capacity (Burhansyah, 2016). Table 1 also shows that in general the respondents of this study had an adequate land area (79.55\%). Generally, the respondents of this study had an area of arable land of 1-2 hectares. With a generally adequate area of arable land, it is expected that it will motivate farmers to cultivate seaweed.

\section{Farmers' Motivation}

Motivation is a human stimulus that greatly influences farmers' behavior to do something (Qonita, 2012). To find out the motivation of farmers in this study, it can be seen in Table 2.

Table 2. The motivation of farmers in cultivating seaweed in Kawite-Wite Village.

\begin{tabular}{cccc}
\hline No & Category (Scoring) & Number of Respondents (People) & Percentage (\%) \\
\hline 1 & High (45-60) & 23 & 52,27 \\
2 & Medium (29-44) & 21 & 47,72 \\
3 & Low (12-29) & - & - \\
\hline & Total & 44 & 100 \\
\hline
\end{tabular}

Source: Processed Primary Data

Motivation is the power that drives someone to do something to achieve goal. Motivation has a big influence on a person's behavior in farming or livestock activities. The reason implies the need or reason for someone to do something (Alam, et al., 2014). Table 2 shows that the majority $(52.27 \%)$ of respondents in this study had good or high motivation in cultivating seaweed. Farmers had high motivation in cultivating seaweed to achieve the goals of cultivating seaweed. Motivations in this study included intensity of farmer activities, (2) persistence of farmers, and (2) farmers' goals in cultivating seaweed.

\section{Intensity}

Motivation is something which drives the desire of people to carry out certain activities to achieve their goals. In the context of work, motivation is an important factor in encouraging someone to work (Nisa, 2015). The intensity of seaweed cultivation in this study showed the extent to which farmers tried to choose the location, choose seeds, plants, care, pest control, harvest, and postharvest seaweed so that they achieve maximum results and achieve their goals. To find out the cultivation of seaweed, see Table 3.

Table 3. Farmers' intensity in seaweed cultivation in Kawite-Wite Village

\begin{tabular}{cccc} 
No & Category (Scoring) & Number of Respondents (People) & Percentage (\%) \\
\hline 1 & High (16-20) & 24 & 54,55 \\
2 & Medium (11-15) & 19 & 43,18 \\
3 & Low (5-10) & 1 & 2,27 \\
\hline & Total & 44 & 100 \\
\hline
\end{tabular}

Source: Processed Primary Data

Motivation is a psychological process, which leads to the emergence, direction, and occurrence of voluntary activities directed towards certain goals (Nisa, 2015). Table 3 shows that most of the respondents (54.55\%) had good or high intensity in working on the stages of seaweed cultivation. Farmers had high enthusiasm to carry out the stages of seaweed cultivation.

\section{Purpose}

Agricultural business is carried out with the aim of increasing farmers' production and income. This goal is what motivates the farmers to continuously survive and achieve the highest profit. The success of an agricultural business is certainly influenced by the motivation of farmers, both internal and external (Nisa, 2015). The seaweed farmers in Kawite-Wite Village have the same goal when developing seaweed farming in which they also already have purpose since they started planting 
seaweed. The description of objectives in the motivation of farmers to cultivate seaweed can be explained in Table 4.

Table 4. The purpose of farmers in seaweed cultivation in Kawite-Wite Village

\begin{tabular}{cccc}
\hline No & Category (Scoring) & Number of Respondents (People) & Percentage (\%) \\
\hline 1 & High (16-20) & 20 & 45,45 \\
2 & Medium (11-15) & 19 & 43,18 \\
3 & Low (5-10) & 5 & 11,36 \\
\hline & Total & 44 & 100 \\
\hline
\end{tabular}

Source: Processed Primary Data

Active motives are driven by various factors which then become the goals to be achieved, both internal and external (Suprayitno, et al., 2015). Table 4 shows that respondents in this research area had very good goals in cultivating seaweed, in which as many as $20(45.46 \%)$ of respondents were in the high or good category. A good goal is a good cause for farmers in seaweed cultivation to motivate them to actively carry out the stages of seaweed cultivation.

\section{Persistence}

Motivation is defined as any power that arises from an individual to achieve certain goals or benefits in the world of work in one's life in general (Datika, et al., 2018). Seaweed is an agricultural product that is very susceptible to pests and diseases and is highly dependent on sea waves (Priono, 2016). Therefore, farmers need the persistence to cultivate seaweed to achieve satisfying results or production with high sales value. An illustration of the persistence of farmers in cultivating seaweed can be seen in Table 5.

Table 5. The persistence of farmers in cultivating seaweed in Kawite-Wite Village

\begin{tabular}{cccc}
\hline No & Category (Scoring) & Number of Respondents (People) & Percentage (\%) \\
\hline 1 & High (16-20) & 20 & 45,45 \\
2 & Medium (11-15) & 20 & 45,45 \\
3 & Low (5-10) & 4 & 9,10 \\
\hline & Total & 44 & 100 \\
\hline
\end{tabular}

Source: Processed Primary Data

The concept of willingness or desire is closely related to the concept of motivation (Suprayitno, et al., 2015). Table 5 shows that some farmers (45.45\%) in this study area had good or high perseverance in cultivating seaweed.

\section{Seaweed Cultivation Activities}

Seaweed is currently being actively developed by the government through cultivation because, in addition to increase fishermen's income, seaweed is also a source of foreign exchange. The algae cultivation aims to increase yields in large quantities, continuously with good quality, especially for export needs. However, if the cultivation business is not well managed and does not pay attention to environmental sustainability and its carrying capacity, this can reduce the quantity and quality of the results obtained (Asaf, et al., 2014).

Seaweed cultivation development areas are generally found in the middle of bay with characteristics of relatively clean water (far from sedimentation), adequate currents, and not too large waves (Radiarta, et al., 2014). Seaweed cultivation includes site selection, seed selection, planting, maintenance, pest and disease control, harvesting, and post-harvest handling. To find out about seaweed cultivation in Kawite-Wite Village, it can be seen in Table 6.

Table 6. Seaweed Cultivation Activities in Kawite-Wite Village.

\begin{tabular}{cccc}
\hline No & Category (Scoring) & Number of Respondents (People) & Percentage (\%) \\
\hline 1 & Good (105 -140) & 23 & 52,27 \\
2 & Fairly good (69-104) & 21 & 47,72 \\
3 & Unfavorable (33-68) & - & \\
\hline & Total & 44 & 100 \\
\hline
\end{tabular}

Source: Processed Primary Data

Seaweed cultivation technology causes seaweed cultivation to become not optimal so that its production is not optimal. Seaweed is prone to shedding, which is one of the obstacles faced by 
farmers in efforts to cultivate optimal seaweed (Sari \& Muslimin, 2015). Table 6 shows that only a large proportion of farmers in the research area $(52.27 \%)$ have cultivated seaweed well.

Algal growth area development has not been identified as a whole. The problem of seaweed in Indonesia is that there is no map of the spatial development area that is compatible with the carrying capacity of the environment. There are also gaps in public information, especially market information, technology information, sources of seeds, pests and diseases, seasons, treatments, until post-harvest and sources of capital (Jailani, et al, 2015). To facilitate the sustainability of seaweed farming activities, a significant increase in the dissemination of scientific information is needed along with recommendations that can be effectively assisted and used by policymakers, as well as spatial planning and resource management with a focus on coastal resources (Radiarta, et al., 2016).

\section{CONCLUSIONS}

The conclusions that can be drawn from this study are: the motivation of farmers in cultivating seaweed is in the high category. Seaweed farmers in the research area have good intensity, goals, and persistence in cultivating seaweed; and farmers' activities in cultivating seaweed in the research area have been carried out well, which include selecting locations, selecting seeds, planting, maintaining, controlling pests and diseases, and harvesting to post-harvest.

\section{REFERENCES}

Alam, A., Dwijatmiko, S., \& Sumekar, W. (2014). Motivasi Peternak Terhadap Aktivitas Budidaya Ternak Sapi Potong Di Kabupaten Buru Provinsi Maluku Farmers. Agromedia.

Anggraeni, D. (2017). Faktor Yang Mempengaruhi Keputusan Petani Dalam Memilih Waktu Panen Jagung (Kasus Pada Petani Jagung Di Kabupaten Serang Provinsi Banten). Mimbar Agribisnis: Jurnal Pemikiran Masyarakat Ilmiah Berwawasan Agribisnis. Https://Doi.Org/10.25157/Ma.V1i1.29

Asaf, R., Makmur, M., \& Suhaemi, R. A. (2014). Upaya Peningkatan Produktivitas Rumput Laut Kappaphycus Alvarezii Dengan Mengetahui Faktor Pengelolaan Di Kabupaten Konawe Selatan Provinsi Sulawesi Tenggara. Jurnal Riset Akuakultur. https://doi.org/10.15578/jra.9.3.2014.463-473

Awaluddin, Badraeni, Azis, H. Y., \& Tuwo, A. (2016). Rumput Laut Indonesia. Jurnal Rumput Laut Indonesia.

Burhansyah, R. (2016). Faktor-Faktor Yang Mempengaruhi Adopsi Inovasi Pertanian Pada Gapoktan Puap Dan Non Puap Di Kalimantan Barat (Studi Kasus: Kabupaten Pontianak Dan Landak). Informatika Pertanian. https://doi.org/10.21082/ip.v23n1.2014.p65-74

Datika, W., Anang, R. H., \& Abubakar, R. (2018). Motivasi Membangun Kebun Jeruk Keprok Rgl (Rimau Gerga Lebong) Di Kelurahan Agung Lawangan Kecamatan Dempo Utara Kota Pagar Alam (Studi Kasus Sidarhan Pemilik Kebun Jeruk Keprok RGL). Societa: Jurnal IImu-IImu Agribisnis. https://doi.org/10.32502/jsct.v7i1.1135

Erniati, E., Zakaria, F. R., Prangdimurti, E., \& Adawiyah, D. R. (2016). Potensi rumput laut: Kajian komponen bioaktif dan pemanfaatannya sebagai pangan fungsional. Acta Aquatica: Aquatic Sciences Journal. https://doi.org/10.29103/aa.v3i1.332

Fikri, M., Rejeki, S., \& Widowati, L. L. (2015). Produksi Dan Kualitas Rumput Laut (Eucheuma Cottonii) Dengan Kedalaman Berbeda Di Perairan Bulu Kabupaten Jepara Production. Journal of Aquaculture Management and Technology.

Herdiansah Sujaya, D., Hardiyanto, T., \& Yuniawan Isyanto, A. (2018). Faktor-Faktor Yang Berpengaruh Terhadap Produktivitas Usahatani Mina Padi Di Kota Tasikmalaya . In Mimbar Agribisnis: Jurnal Pemikiran Masyarakat IImiah Berwawasan Agribisnis.

Hernanto, A. D., S. R. dan R. W. A. (2015). Pertumbuhan budidaya rumput laut (Eucheuma cottoni dan Gracilaria sp.) dengan metode long line di Perairan Pantai Bulu Jepara. Journal of Aquaculture Management and Technology. https://doi.org/10.1016/j.cmet.2009.10.009

Hikmah, H. (2015). Strategi Pengembangan Industri Pengolahan Komoditas Rumput Laut E. Cotonii Untuk Peningkatan Nilai Tambah Di Sentra Kawasan Industrialisasi. Jurnal Kebijakan Sosial Ekonomi Kelautan Dan Perikanan. https://doi.org/10.15578/jksekp.v5i1.1013

Jailani E, Y., Semedi, Bambang, A. Q. H. (2015). Studi Kelayakan Lahan Budidaya Rumput Laut Eucheuma Cottonii Di Kecamatan Bluto Sumenep Madura Jawa Timur. Jurnal Manusia Dan Lingkungan (Journal of People and Environment).

Kesuma, C. P., Adi, A. C., \& Muniroh, L. (2015). Pengaruh substitusi rumput laut (Eucheuma cottonii) dan jamur tiram (Pleurotus ostreatus) terhadap daya terima dan kandungan serat pada 
biskuit. Media Gizi Indonesia.

Linarwati, M. dkk. (2016). Studi Deskriptif Pelatihan Dan Pengembangan Sumberdaya Manusia Serta Penggunaan Metode Behavioral Event Interview Dalam Merekrut Karyawan Baru Di Bank Mega Cabang Kudus. Journal of Management. https://doi.org/10.1016/j.bpc.2013.02.004

Mahyuddin, T., \& Windasari, N. (2017). Persepsi Petani Tehadap Penggunaan Teknologi Pada Budidaya Kacang Panjang (Vigna Sinensis) Di Kecamatan Manyak Payed Kabupaten Aceh Tamiang. Jurnal Penelitian Agrisamudra. https://doi.org/10.33059/jpas.v4i1.263

Marti S, H., Wulandari, C., \& Hilmanto, R. (2014). Motivasi Petani Dalam Budidaya Lebah Madu (Apis Cerana) Di Desa Buana Sakti Kabupaten Lampung Timur. Jurnal Sylva Lestari. https://doi.org/10.23960/jsl3273-82

Nisa, N. K. (2015). Motivasi Petani dalam Menanam Komoditas Padi Pada Daerah Lumbung Padi Di Kabupaten Gresik. Swara Bhumi.

Priono, B. (2016). Budidaya Rumput Laut Dalam Upaya Peningkatan Industrialisasi Perikanan. Media Akuakultur. https://doi.org/10.15578/ma.8.1.2013.1-8

Qonita, A. (2012). Motivasi Kerja Utama Petani Dalam Kemitraan Dengan Pusat Pengolahan Kelapa Terpadu Di Kabupaten Kulon Progo. Sepa.

Radiarta, I. N., Erlania, E., \& Sugama, K. (2014). Budidaya Rumput Laut, Kappaphycus Alvarezii Secara Terintegrasi Dengan Ikan Kerapu Di Teluk Gerupuk Kabupaten Lombok Tengah, Nusa Tenggara Barat. Jurnal Riset Akuakultur. https://doi.org/10.15578/jra.9.1.2014.125-134

Radiarta, N., Erlania, E., Haryadi, J., \& Rosdiana, A. (2016). Analisis Pengembangan Budidaya Rumput Laut Di Pulau Sebatik, Kabupaten Nunukan, Kalimantan Utara. Jurnal Kebijakan Perikanan Indonesia. https://doi.org/10.15578/jkpi.8.1.2016.29-40

Sari, W. K. P., \& Muslimin. (2015). Budidaya Rumput Laut Sargassum sp. Pada perairan dengan substrat dasar berbeda. In Jurnal STP.

Suharsimi, A. (2013). Prosedur Penelitian: Suatu Pendekatan Praktik (Edisi Revisi). Jakarta: Rineka Cipta. https://doi.org/10.1017/CBO9781107415324.004

Sujarwo, P. A., \& Fitriyanny, W. P. (2016). Pengelolaan Budidaya Rumput Laut Berkelanjutan Untuk Masyarakat Pesisir Pulau Panjang Serang, Banten. Jurnal Kebijakan Sosial Ekonomi Kelautan Dan Perikanan. https://doi.org/10.15578/jksekp.v6i2.3326

Sunyoto, D. (2012). Statistik Kesehatan; Analisis Data Dengan Perhitungan Manual Dan Program SPSS. In Nuha Medika. https://doi.org/10.1016/S0969-4765(04)00066-9

Suprayitno, A. R., Sumardjo, S., Gani, D. S., \& Sugihen, B. G. (2015). Motivasi dan Partisipasi Petani dalam Pengelolaan Hutan Kemiri di Kabupaten Maros Provinsi Sulawesi Selatan. Jurnal Penyuluhan. https://doi.org/10.25015/penyuluhan.v8i2.9883

Yasmiati. (2010). Hubungan Faktor-Faktor Sosial Ekonomi dan Psikologi dengan Tingkat Penerimaan Usaha Tani Padi. Wacana. 